\title{
Antigenic Stimuli do not Influence Thymic B Lymphocytes: A Morphological and Functional Study in Germ-Free and Conventionally Reared Piglets
}

\author{
B. CUKROWSKA ${ }^{a^{*}}$ I. TREBICHAVSKÝa P. ROSSMANN ${ }^{a}$ Z. ŘEHÁKOVÁa J. ŠINKORA ${ }^{a}$ K. HAVERSON ${ }^{b}$ R. \\ LODINOVÁ-ŽÁDNÍKOVÁc ${ }^{\mathrm{a}}$ and H. TLASKALOVÁ-HOGENOVÁa \\ a Department of Immunology and Gnotobiology, Institute of Microbiology, Academy of Sciences of the Czech Republic, Videñská 1083, \\ 14220 Prague 4, Czech Republic; ' ${ }^{\mathrm{b}}$ Department of Clinical Veterinary Science, University of Bristol, Langford BS18 7DY, United \\ Kingdom; 'Institute for Care of Mother and Child, Prague, Czech Republic
}

(Received 12 August 1996; Accepted 14 August 1996; In final form 2 May 1997)

\begin{abstract}
We have recently reported that thymic B lymphocytes (TBL) are the first B-cell subpopulation undergoing isotype switching to $\mathrm{IgG}$ and $\mathrm{IgA}$ during embryonic life. The aim of this study is to analyze the influence of antigenic stimulation on TBL location and activity using a germ-free (GF) newborn pig model, in which maternal antibodies and antigens do not affect B-cell development. Immunohistological analysis showed that TBL were disseminated mainly in the thymic medulla. There were no differences in the distribution of TBL, both in GF newborn piglets before and after colonization with Escherichia coli and in older conventionally reared (CONV) piglets. The number of immunoglobulin (Ig)-secreting cells measured by the ELISPOT method was not influenced by microflora and food antigens. IgM-positive cells secreting IgM and CD45RC-positive cells spontaneously producing $\operatorname{IgM}, \operatorname{IgG}$, and $\operatorname{IgA}$ were detected in newborn thymus.

Our findings suggest that TBL differentiation and Ig switching to IgG and IgA-secreting cells is not influenced by external antigens and that the thymic microenviroment plays an important role in this process.
\end{abstract}

Keywords: Thymic B lymphocytes, B-cell differentiation, ELISPOT, pig

\section{INTRODUCTION}

The existence of thymic B lymphocytes (TBL) as a constant component of the thymic medulla has been described recently (Isaacson et al., 1987; Inaba et al., 1988, Andreu-Sanchez et al., 1990; Bianchi et al., 1992; Spencer et al., 1992). Unique phenotypic and morphological features of TBL distinguish them from

\footnotetext{
${ }^{*}$ Corresponding author. Present address: Department of Immunology and Gnotobiology, Institute of Microbiology, Academy of Sciences of the Czech Republic, Vídeňská 1083, 14220 Prague 4, Czech Republic.
} 
peripheral lymphocytes. The majority of murine and human TBL express the CD5 molecule (Inaba et al., 1988; Punnonen and de Vries, 1993), but, in contrast to B-1 cells, TBL are derived from the bone marrow (Than et al., 1992). Human TBL also bear the CD2 antigen, characteristic for human $\mathrm{T}$ lymphocytes (Punnonen and de Vries, 1993). Recently, fetal TBL from human and pig have been shown to undergo isotype switching to $\mathrm{IgA}$ and $\mathrm{IgG}$-secreting cells in a similar fashion as mature conventional B cells (Punnonen and de Vries, 1993; Cukrowska et al., 1996a). The mechanism of activation and the factors influencing TBL differentiation to immunoglobulin (Ig)-secreting cells remain unclear. The importance of direct T-cell interaction and cytokines in their maturation has been recently confirmed by functional analyses of murine and human TBL (Inaba et al., 1990, 1995; Punnonen and de Vries, 1993).

To investigate the characteristics of TBL, we used a unique pig model. In contrast to mice and humans, in which B-cell development is influenced by maternal antibodies and antigens (Kearney and Vakil, 1986), pigs have a special six-layered placenta preventing the transfer of maternal regulatory factors to the embryo. Transfer of maternal Igs occurs after suckling maternal colostrum (Šterzl et al., 1965). For this reason, pig fetuses and colostrum-deprived piglets reared in germ-free (GF) conditions are very useful experimental models that allow to differentiate between innate factors and factors arising under the influence of passively acquired antibodies and external antigenic stimuli (Tlaskalová-Hogenová et al., 1983). We have observed, using the ELISPOT method, that the fetal pig thymus contains Igsecreting cells very early in embryonic life (Prokešová et al., 1981; Cukrowska et al., 1996a). In contrast to fetal splenic B cells, which have been found to produce exclusively IgM, fetal thymic B cells of the same age undergo spontaneous and after in vitro polyclonal activation isotype switching into $\mathrm{IgG}$ and IgA (Cukrowska et al., 1995, 1996a).

In the present study, we analyze the influence of external antigenic stimuli on spontaneous Ig production by TBL and on the location of B cells in the pig thymus.

\section{RESULTS}

Location of Thymic B Cells in GF Newborns, GF Piglets Colonized with Escherichia coli and Conventionally Reared (CONV) Piglets

The newborn pig thymus displayed sparsely scattered lymphocytes expressing membrane-bound Igs (Fig. 1, left). Most cells were seen in the medulla, without an apparent accumulation or follicular structures. There was no agglomeration around the Hassall's bodies. Single contoured cells were noted in the cortex in lower numbers than in the medulla (by 1 to 2 orders of magnitude). The reaction with the pig anti-rabbit antibody was negative. The deep cortex and medulla harbored larger cells with coarse cytoplasmic DABreactive granules (macrophages). This staining of macrophages was unchanged after omission of the antibodies (Fig. 1, right).

The adult pig thymus exhibited a similar distribution of Ig-positive lymphocytes as in GF newborn piglets; macrophages were concentrated in the corticomedullary junction (data not shown). The stimulation of GF piglets by Escherichia coli O86 elicited an increase in endogenous peroxidase-reactive macrophages, whereas Ig-positive lymphocytes remained scarce and no follicular agglomeration was found (Fig. 2, left). In contrast to the scattered distribution of TBL, splenic Ig-positive cells were assembled to follicles (Fig. 2, right).

\section{Spontaneous Ig Production Measured by the ELISPOT Assay}

As shown by immunohistological studies, the location and organization of TBL was not altered by antigenic stimuli; we also tried to analyze the functional state of these cells by measuring spontaneous Ig production. Conventional microflora and food antigens influenced neither the number of spot-forming cells nor the isotype pattern of Ig production by TBL. In contrast to splenic B cells of CONV piglets that showed a significant increase in Ig-secreting cells of all isotopes, the thymus of CONV piglets and GF newborns contained comparable numbers of IgM-, IgG-, and IgA-secreting cells (Figure 3). The experimental 


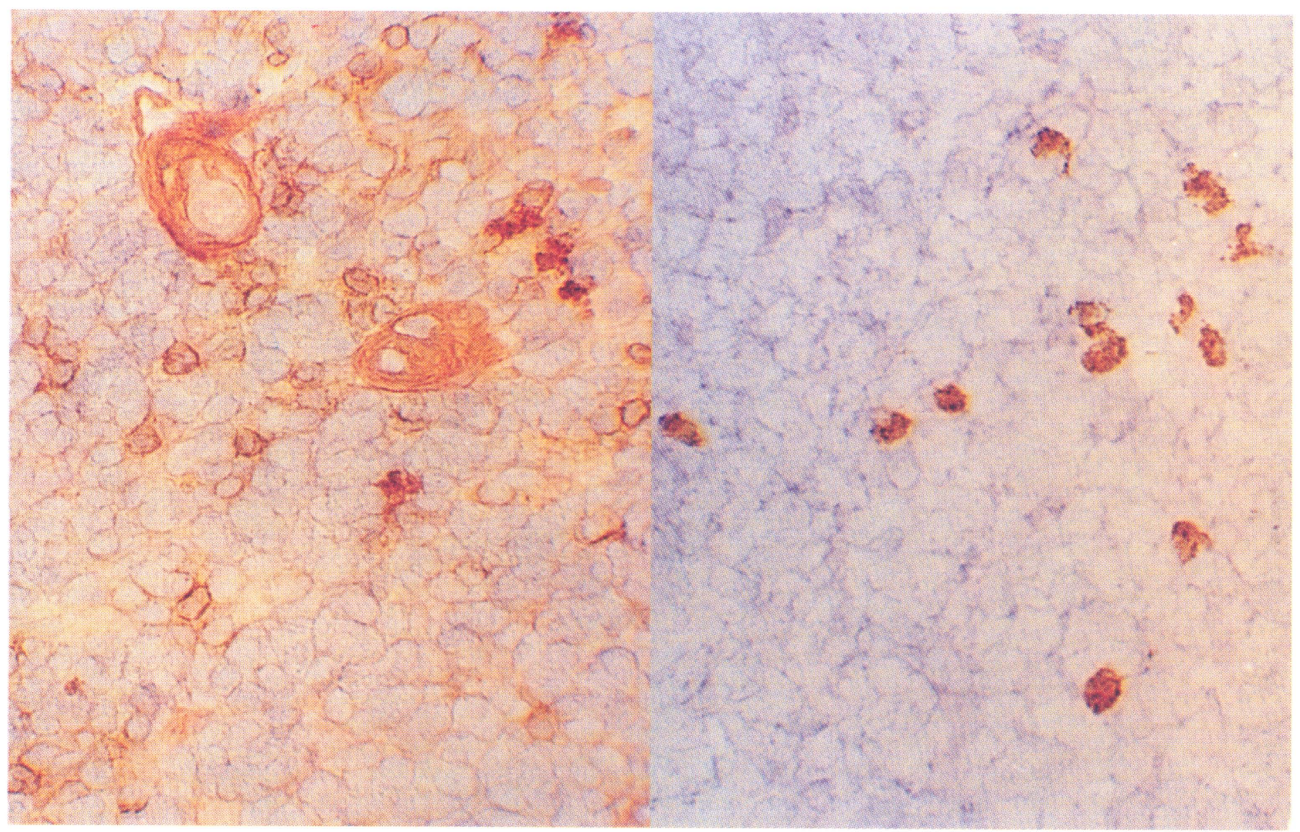

FIGURE 1 Left: Scattered lymphocytes expressing surface Igs in thymic medulla of a GF newborn piglet. Two Hassal bodies and several macrophages with coarse cytoplasmic granules are seen. RASW-HRP. Right: Same animal. Endogenic peroxidase in thymic medullar macrophages. DAB- $\mathrm{H}_{2} \mathrm{O}_{2}$. (See Color Plate XIII)

colonization of GF piglets with E. coli O86 did not change the number of Ig-secreting cells in the thymus.

\section{Ig Secretion by Enriched Thymic B Cells}

A separation method using anti-pig IgM monoclonal antibody (mAb) allowed us to enrich IgM-positive TBL from $<0.5 \%$ to $>90 \%$ as measured by flow cytometry (data not shown). These cells were able to produce mainly the IgM isotype. Spontaneous IgAand IgG-secreting cells were found occasionally in this highly purified subpopulation (Fig. 4). To enrich TBL-secreting IgG and IgA, we used anti-CD45RC mAb (Saallmüler 1996), which reacts with all Igpositive B lymphocytes in pigs (unpublished data). In contrast to $\mathrm{IgM}^{+} \mathrm{TBL}, \mathrm{CD} 45 \mathrm{RC}$-positive cells from thymus of GF newborns were shown to secrete Igs of all isotypes (Fig. 4). This effect was not observed when splenic cells of the same animals were used: B cells enriched from spleen by anti-CD45RC mAb produced mainly IgM (data not shown).

\section{DISCUSSION}

Recent in vitro experiments in murine and human systems indicate that TBL are activated in a different manner than both conventional (B-2) cells and peritoneal (B-1) cells (Inaba et al., 1990, 1995; Punnonen and de Vries, 1993). Indeed, our earlier studies have shown that in contrast to fetal splenic cells, which secrete exclusively IgM, TBL isolated from pig fetuses are capable of spontaneous production of IgM, IgG, and IgA (Cukrowska et al., 1996a). We have found that during the embryonic life, the number of thymic Ig-secreting cells of all isotypes increase progressively and reach a maximum by the end of gestation. By using pig fetuses, which are devoid of transferred maternal antibodies and antigens, the effect of external antigens on the immune system can be ruled out. 


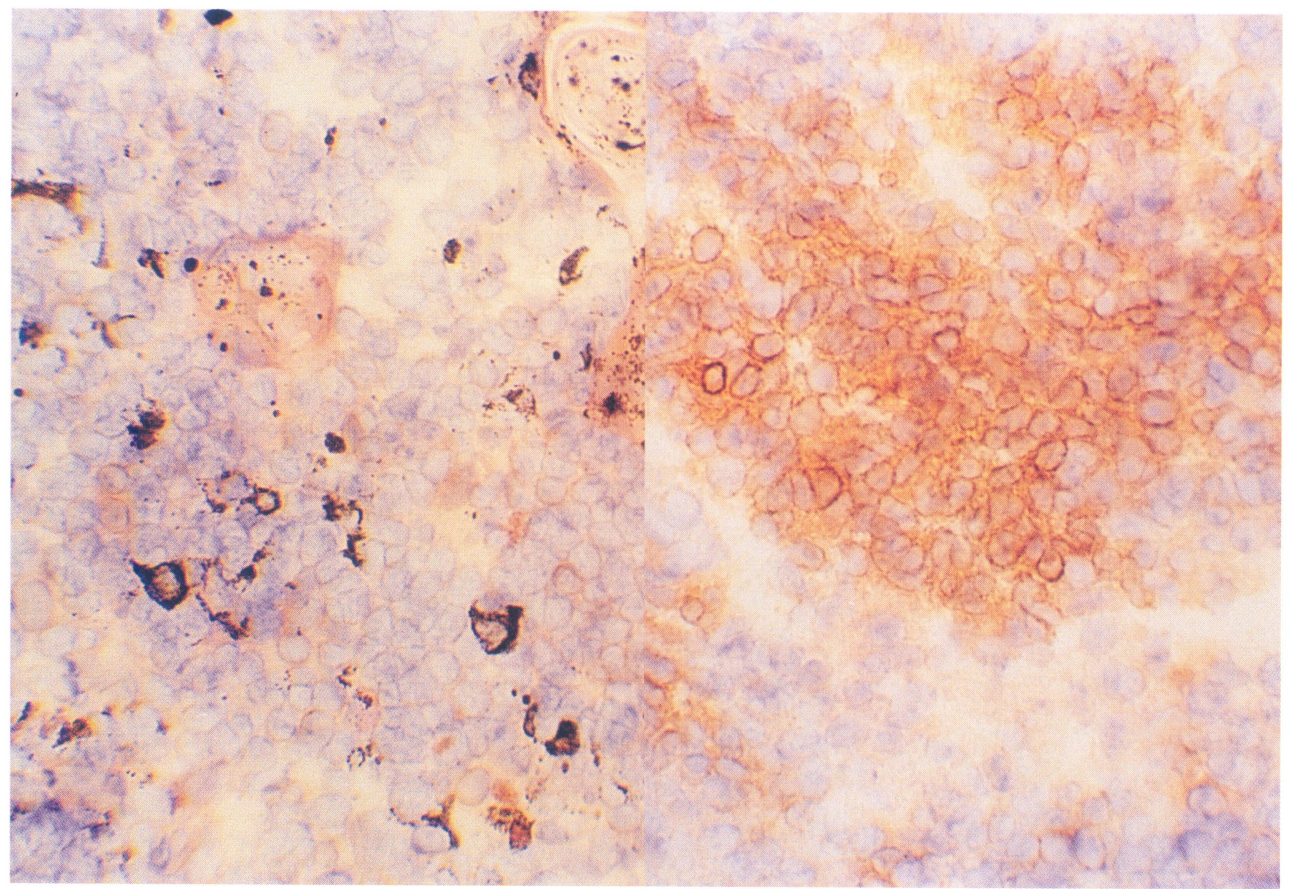

FIGURE 2 Left: Scattered lymphocytes with surface Igs and macrophages with endogenous peroxidase granules in thymic medulla of a GF piglet colonized with Escherichia coli. RASW-HRP. Right: Same animal. Splenic white pulp with agglomerated B lymphocytes. RASWHRP. (See Color Plate XIV)

In this paper, we studied the influence of naturally occurring stimulation by food and microflora antigens after the birth to conventional conditions on the location and differentiation of thymic B cells. Pig TBL were shown to be disseminated mainly throughout the thymic medulla, and this finding is in line with earlier studies on human TBL (Fend et al., 1991; Spencer et al., 1992). However, in contrast to the human thymus, we did not observe clustering of B lymphocytes around Hassal's bodies in the pig thymus. A location of thymic B cells resembling that in GF newborns was found in both immunized GF and CONV piglets. The stable number of TBL was also found in the thymus of fetuses after intrauterine immunization with different bacterial components (our unpublished data). Thus, in contrast to B cells of peripheral lymphoid organs of GF animals, in which external antigens generate germinal centers (Tlaskalová-Hogenová et al., 1983), the antigenic stimuli did not influence the distribution of TBL. The analysis of spontaneous Ig production also confirmed the absence of influence of external bacterial antigens on TBL differentiation: The isotype pattern of thymic Igsecreting cells and the quantity of spot-forming cells was similar both in immunized GF and CONV piglets when compared to GF newborn animals. These findings indicate that $\mathrm{B}$ cells localized in the thymus do not respond to bacterial antigens as splenic $B$ lymphocytes do. The existence of mature B lymphocytes secreting Igs of all isotypes in GF newborn thymus emphasizes the basic role of the thymic microenviroment and probably autoantigens in TBL maturation. Thus, our results support the idea that TBL are activated by the direct interaction of TCR/ $\mathrm{CD} 3$ complex on $\mathrm{T}$ cells with self-peptide/MHC receptor on TBL and that the pattern of isotype switching to $\operatorname{IgG}$ and $\operatorname{IgA}$ can be induced by signal through CD40 ligand-CD40 (Inaba et al., 1995).

We showed that TBL represent a unique B-cell subpopulation undergoing maturation and isotype switching early in ontogeny without activation by exogenous antigens. As TBL do not play the direct 

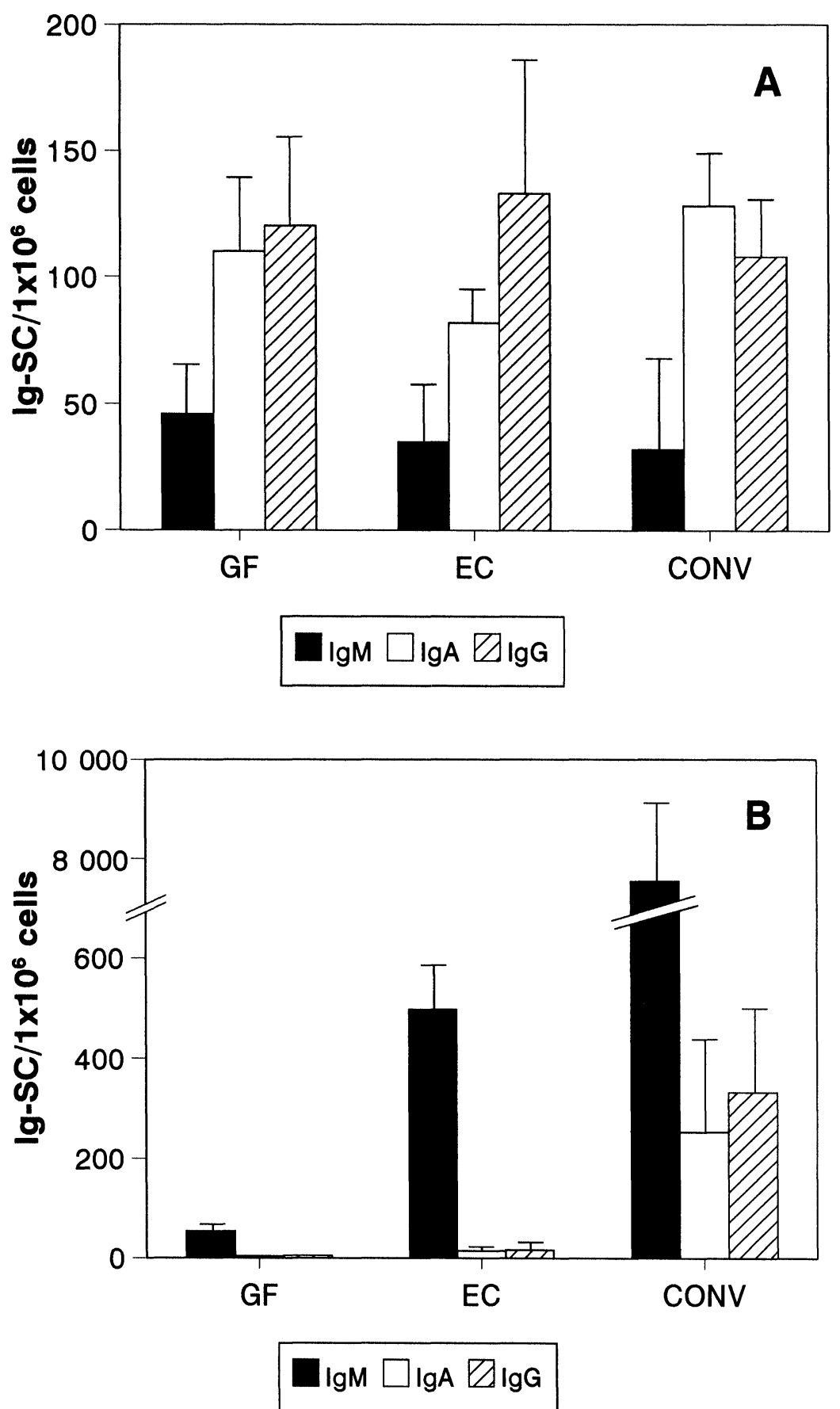

FIGURE 3 Spontaneous Ig production in (A) thymus and (B) spleen of GF newborns, GF piglets colonized by E. coli O86 and CONV piglets. Ig production in thymic- and splenic-cell suspensions was measured by the ELISPOT method. The results are determined as the number of Ig-secreting cells (Ig-SC) per $10^{6}$ nucleated cells; arithmetical means \pm SD from four animals are shown. GF, GF newborns; EC, GF piglets colonized by $E$. coli; CONV, conventionally reared piglets. 
role in immune response against microflora, the problem of their biological functions is still open. The role of TBL as antigen-presenting cells in shaping of T-cell repertoire has been proposed (Inaba et al., 1991, Mazda et al., 1991). Mouse thymic B cells, but not splenic cells were found to induce tolerance by a deletion mechanism. However, in the light of recent findings on the importance of natural autoantibodies in selection processes (Holmberg and Kearney 1994), it cannot be excluded that Igs spontaneously secreted by TBL locally influence T-cell development. Analyses of the antibody specificity produced by TBL during ontogeny is still lacking. Interestingly, we have recently reported a pronounced reactivity of "preimmune" Igs, that is, isolated from fetal and GF newborn sera with pig thymocytes (TlaskalováHogenová et al., 1994; Cukrowska et al., 1996b).

\section{MATERIALS AND METHODS}

\section{Animals}

Colostrum-deprived Miniature Minnesota pig newborns 1 day old were used. Some fetuses were kept in isolators after a gnotobiotic hysterectomy and were given a sterilized milktype diet (Travníček et al., 1966). The germ-free state was controlled twice a week by an aerobic and anaerobic cultivation of a

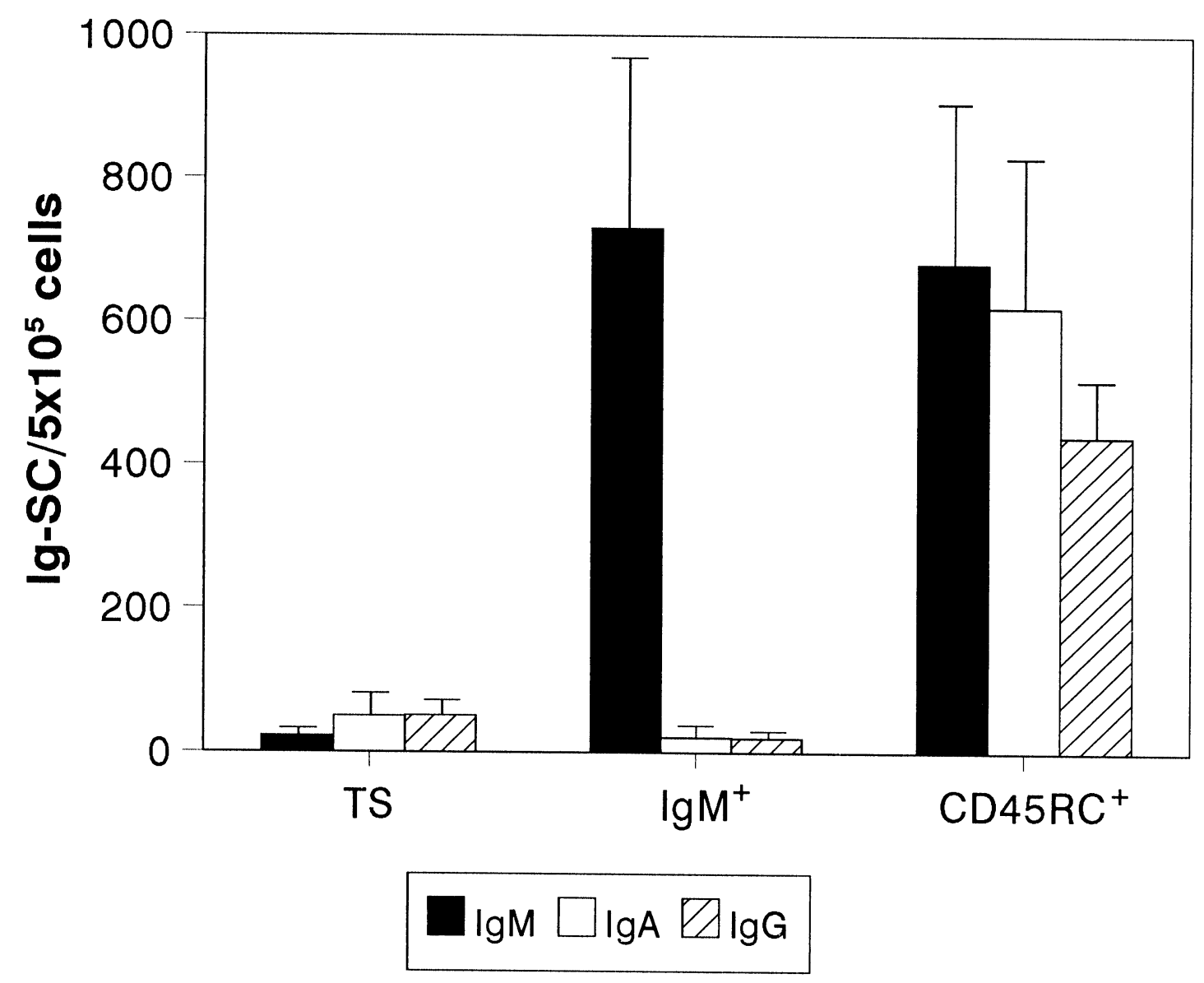

FIGURE 4 Spontaneous Ig production by thymic IgM-positive and CD45RC-positive cells. Cells were separated from GF newborn thymocytes on miniMACS column by anti-pig IgM and anti-pig CD45RC mAb. Ig production was measured by the ELISPOT method. The results are determined as the number of Ig-secreting cells $(\mathrm{Ig}-\mathrm{SC})$ per $5 \times 10^{5}$ nucleated cells; arithmetical means \pm SD from five animals are shown. TS, thymic-cell suspension. 
rectal swab. GF piglets received $5 \times 10^{8}$ nonpathogenic E. coli $O 86$ in the milk from the fifth day after the birth. On day 7 after colonization, animals were exsanguinated under anesthesia and lymphoid organs were taken for cell isolation. CONV piglets, 2 to 3 months old were also used.

\section{Isolation of Cells}

The lymphoid organs were gently minced in RPMI1640 medium, filtrated trough a nylon mesh, washed three times in the medium, and than resuspended in the complete RPMI-1640 medium supplemented by $10 \%$ fetal calf serum and gentamycin.

\section{Immunohistochemistry}

Pig Ig-positive cells were detected on acetoneextracted cryostat sections $(6 \mu \mathrm{m})$ of unfixed frozen pig thymus by one-step direct immunoenzyme test using the HRP-labeled rabbit anti-swine antibody (RASW-HRP) diluted 1:40 (Sevac, Prague, Czech Republic). The incubation was $1 \mathrm{hr}$ at room temperature and the bound enzyme was developed with DAB$\mathrm{H}_{2} \mathrm{O}_{2}$ reagent. The control test involved incubation with an antibody of different specificity (HRPcoupled swine anti-rabbit) or incubation with DAB$\mathrm{H}_{2} \mathrm{O}_{2}$ alone.

\section{Detection of Spontaneously Ig-Secreting Cells}

The number of spontaneously Ig-secreting cells of all isotypes was determined by the ELISPOT method using anti-pig isotype-specific mAb as previously described (Cukrowska et al., 1996a). The following murine anti-pig mAb were used: anti-IgM (LIG-4) (Dvořak et al. 1986), anti-IgG (23.3 1a), anti-IgA (27.9.1), anti-light chain (27.7.1 and 27.2.1) (van Zaane and Holst, 1987) (the kind gift from A.T.J. Bianchi, Lelystad, the Netherlands). In order to confirm that spot formation was constituted as a result of Ig synthesis during the in vitro incubation, an inhibition of protein synthesis by cycloheximide (Sigma, St.Louis) was conducted (Cukrowska et al., 1996a). This treatment abrogated the spot formation of all isotypes, thus demonstrating that this assay detects cells synthesizing and actively secreting Igs.

\section{Enrichment of B Lymphocytes from Thymus}

A positive separation procedure by the magnetic miniMACS column (Miltenyi Biotech, Bergish-Gladbach, Germany) was performed using anti-pig IgM and anti-pig CD45RC mAb (Saalmüller 1996) to enrich B lymphocytes from newborn thymus according to manufactural instructions. Separated lymphocytes were spun down, resuspended in 10\% RPMI1640 medium, and used for detection of Ig secretion by the ELISPOT method. The purity of separated cells was $>90 \%$ as assessed by flow cytometry. Magnetic microbeads and/or mAb had no effect on spontaneous Ig secretion (data not shown); thus, we could rule out the possible activation of cells by $\mathrm{mAb}$ and magnetic microbeads.

\section{Acknowledgements}

The authors thank Andre Bianchi for the generous gift of the isotype-specific mAbs. This work was supported by grants 303/96/1256, 302/94/0051 from the Grant Agency of the Czech Republic, grant 3761-3 from the Grant Agency of the Ministry of Health of the Czech Republic and EC copernicus grant CIPACT-940209.

\section{References}

Andreu-Sanchez J.L., Faro J., Alonso J.M., Paige Ch. J., Martinez A.C., and Marcos M. (1990). Ontogenic characterization of thymic B lymphocytes. Analysis in different mouse strains. Eur. J. Immunol. 20: 1767-1773.

Bianchi A.T.J., Zwart R.J., Jeurissen S.H.M., and Moonen-Leusen H.W.M. (1992). Development of the B- and T-cell compartments in porcine lymphoid organs from birth to adult life: An immunohistological approach. Vet. Immunol. Immunopathol. 33: 201-221.

Cukrowska B., Šinkora J., Mandel L., Šplíchal I., Bianchi A.T.J., Kovářu F., and Tlaskalová-Hogenová H. (1996a). Thymic B cells spontaneously produce IgM, IgG and IgA in pig fetuses and germ-free pigs: Detection by ELISPOT method. Immunology 87: 487-492.

Cukrowska B., Šinkora J., Řeháková Z., Šinkora M., Šlíchal I., Tučková L., Avrameas S., Saalmüller A., Barot-Ciorbaru R., and 
Tlaskalová-Hogenová H. (1996b). Isotype and antibody specificity of spontaneously formed immunoglobulins in pig fetuses and germ-free piglets: Production by $\mathrm{CD}^{-} \mathrm{B}$ cells. Immunology 88: 611-617.

Cukrowska B., Šinkora J., Řeháková Z., Šplíchal I., Tučková L., Barot-Ciorbaru R., Bianchi A.T.J., Lodinová-Žadniková R., and Tlaskalová-Hogenová H. (1995). Polyclonal immunoglobulin response of thymic, hepatic and splenic lymphocytes from fetal, germ-free and conventionally reared pigs to different $\mathrm{B}$ cell activators. Folia Microbiol. 40: 421-430.

Dvořák P., Dvořákova D., Hruban V., Hořak V., and Staněk R. (1986). Monoclonal antibodies specific for pig serum and cell surface IgM. Res. Vet. Sci. 41: 356-361.

Fend F., Nachbaur D., Oberwasserlechner F., Kreczy A., Huber H., and Müller-Hermelink H.K. (1991). Phenotype and topography of human thymic B cells. An immunohistologic study. Virchows Archiv. B Cell.Pathol. 60: 381-388.

Holmberg D., and Kearney J. (1994). Selection of the B-cell repertoire and natural autoantibodies. In Autoimmunity: Physiology and Disease, Coutinho A., and Kazatchkine M.D., Eds. (New York: Wiley-Liss), pp. 89-107.

Inaba M., Inaba K., Adachi Y., Nango K., Ogata H., Muramatsu S., and Ikehara S. (1990). Functional analyses of thymic $\mathrm{CD}^{+}$B cells. Responsiveness to Major Histocompatibility Complex class II-restricted T blasts but not lipopolysaccharide or anti-IgM plus interleukin 4. J. Exp. Med. 171: 321-326.

Inaba M., Inaba K., Fuluba Y., Mori S., Haruna H., Doi H., Adachi Y., Iwai H., Hosaka N., and Hisha H. (1995). Activation of thymic B cells by signal of CD40 molecules plus interleukin- 10 . Eur. J. Immunol. 25: 1244-1248.

Inaba M., Inaba K., Hosono M., Kumamoto T., Ishida T., Muramatsu S., Masuda T., and Ikehara S. (1991). Distinct mechanisms of neonatal tolerance induced by dendritic cells and thymic B cells. J. Exp. Med. 173: 549-559.

Inaba M., Kuma S., Inaba K., Ogata H., Iwai H., Yasumizu R., Muramatsu S., Steiman R.M., and Ikehara S. (1988). Unusual phenotype of B cells in the thymus of normal mice. J. Exp. Med. 168: $811-816$.
Isaacson P.G., Norton A.J., and Addis B.J. (1987). The human thymus contains a novel population of B lymphocytes. Lancet 2: $1488-1491$.

Kearney J., and Vakil M. (1986). Idiotype-directed interactions during ontogeny play a major role in the establishment of the adult B cell repertoire. Immunol. Rev. 94: 39-50.

Mazda O., Watanabe Y., Gyotoku J.I., and Katsura Y. (1991). Requirement of dendritic cells and B cells in clonal deletion of MLs-reactive $\mathrm{T}$ cells in the thymus. J. Exp. Med. 173: 539-547.

Prokešová L., Trebichavský I., Kovářů F., Kostka J., and Rejnek J. (1981). Ontogeny of immunoglobulin synthesis. Production of IgM, IgG and IgA in pig foetuses. Dev. Comp. Immunol. 5: 491-499.

Punnonn J., and de Vries J.E. (1993). Characterization of a novel $\mathrm{CD} 2^{+}$human thymic B cell subset. J. Immunol. 151: 100-110.

Saalmüller A. (1996). Characterization of swine leukocyte differentiation antigens. Immunol. Today 17: 352-354.

Spencer J., Choy M., Hussell T., Papadaki J., and Isaacson P.G. (1992). Properties of human thymic B cells. Immunology 75: 596-600.

Šterzl J., Rejnek J., and Travníček J. (1965). Impermeability of pig placenta for antibodies. Folia Microbiol. 11: 7-10.

Than S., Inaba M., Inaba K., Fukuba Y., Adachi Y., and Ikehara S. (1992). Origin of thymic and peritoneal Ly-1 B cells. Eur. J. Immunol. 22: 1299-1303.

Tlaskalová-Hogenová H., Mandel L., Trebichavský I., Kovářo̊ F., Barot R., and Šterzl J. (1994). Development of immune responses in early pig ontogeny. Vet. Immunol. Immunopathol. 43: $135-142$.

Tlaskalová-Hogenová H., Šterzl J., Štěpáková R., Dlabač V., Větvička V., Rossmann P., Mandel L., and Rejnek J. (1983) Development of immunological capacity under germfree and conventional conditions. Ann. N.Y. Acad. Sci. 409: 96-113.

Travníček J., Mandel L., Lanc A., and Rủžička R. (1966). Rearing of germfree piglets (in Czech). Čs. Fysiol. 15: 240-246.

Van Zaane D., and Hulst M.M. (1987). Monoclonal antibodies against porcine immunoglobulin isotypes. Vet. Immunol. Immunopathol. 16: 23-36. 


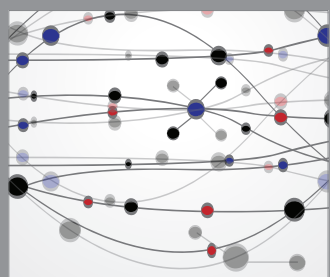

The Scientific World Journal
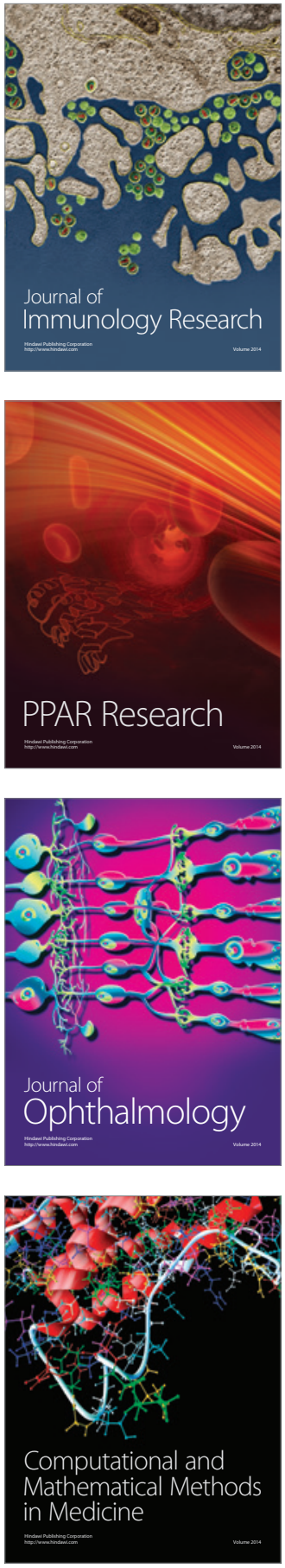

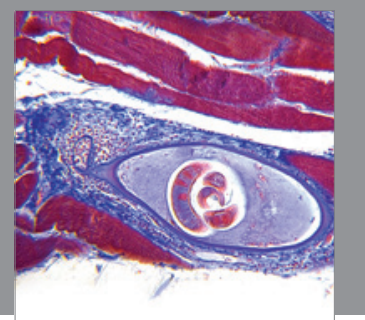

Gastroenterology

Research and Practice
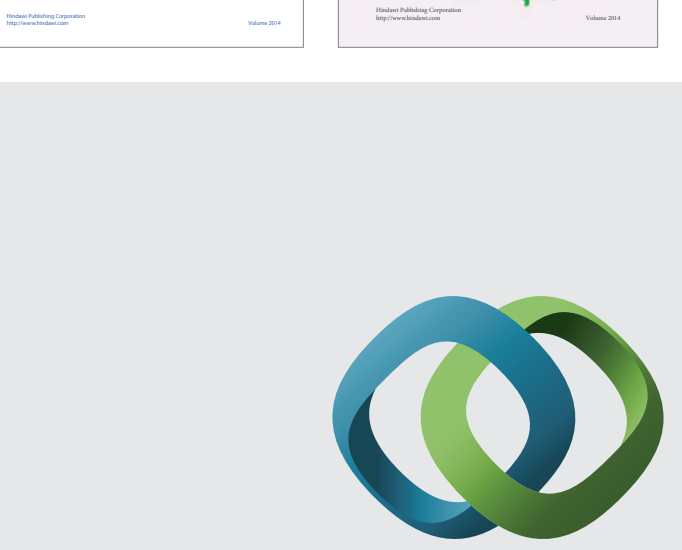

\section{Hindawi}

Submit your manuscripts at

http://www.hindawi.com
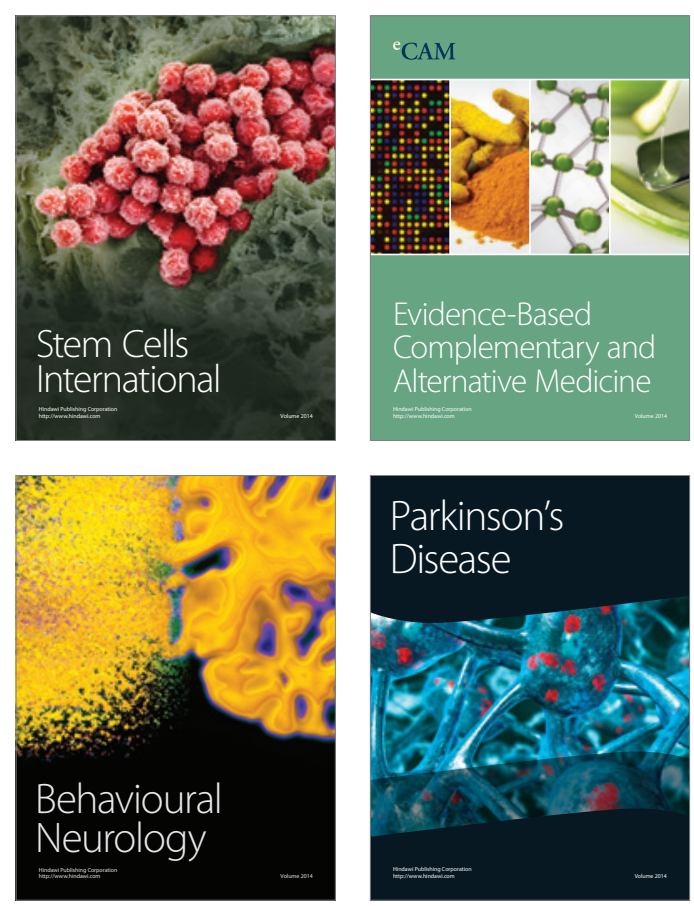

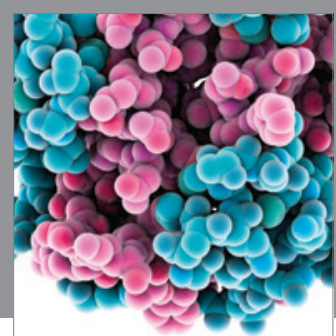

Journal of
Diabetes Research

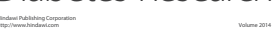

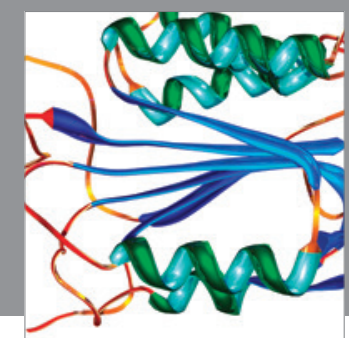

Disease Markers
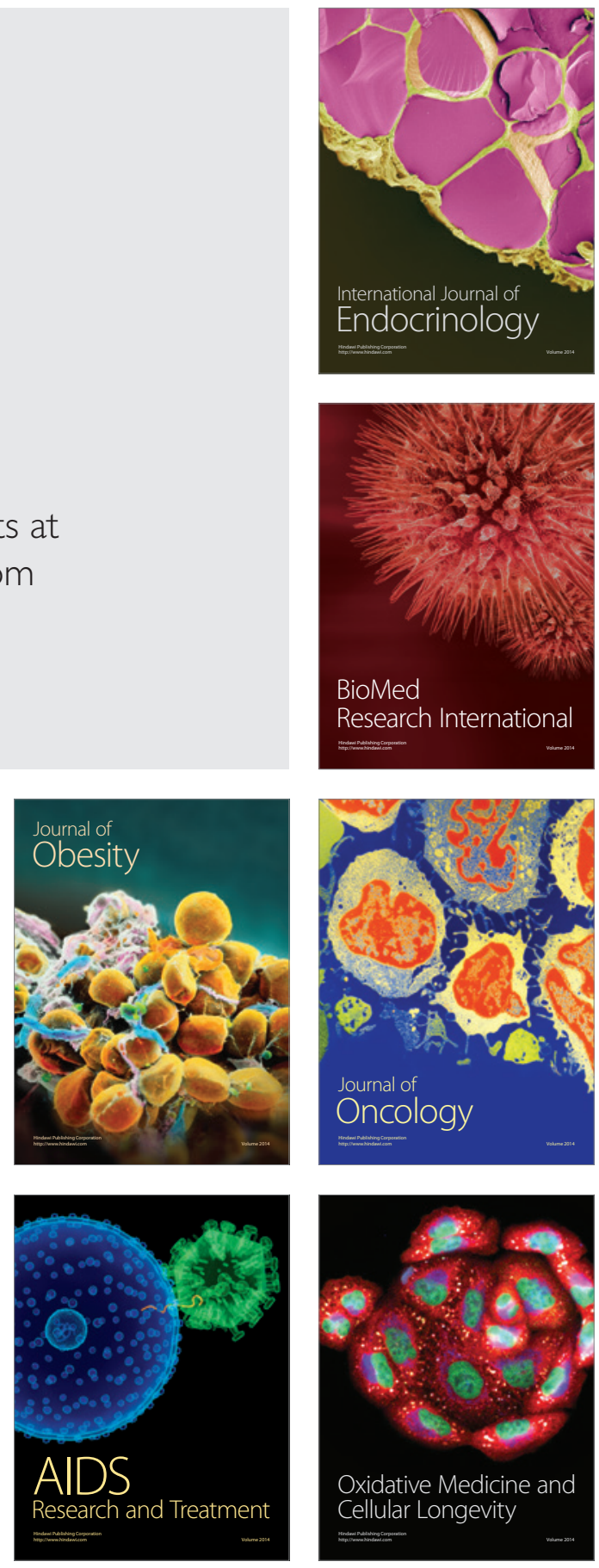